\title{
PERLINDUNGAN HUKUM TERHADAP TARIF PENGGUNA JASA ANGKUTAN UMUM BERBASIS ONLINE
}

\author{
Oleh: Pendi Ahmad, SH., MH. \\ Dosen Universitas Pamulang \\ pendiahmad158@gmail.com
}

\begin{abstract}
Abstrak
Penyelenggaraan lalu-lintas dan angkutan jalan juga perlu dilakukan secara berkesinambungan dan terus ditingkatkan agar lebih luas jangkauan dan pelayanannya kepada masyarakat, dengan tetap memperhatikan kepentingan umum, kemampuan masyarakat, kelestarian lingkungan, dan ketertiban masyarakat dalam penyelenggaraan lalu dan kepentingan masyarakat umum sebagai pengguna jasa transportasi perlu mendapatkan prioritas dan pelayanan yang optimal baik dari pemerintah maupun penyedia jasa transportasi.

Tujuan dari penelitian ini adalah mengetahui perlindungan hukum terhadap tarif pengguna jasa angkutan umum berbasis online ditinjau dari Undang-Undang Nomor 22 Tahun 2009 Tentang Lalu Lintas dan Angkutan Jalan dan Peraturan Pemerintah Nomor 32 Tahun 2016 tentang Penyelenggaraan Angkutan orang dengan Kendaraan Bermotor Umum tidak dalam Trayek, mengetahui bentuk penetapan tarif pengguna jasa angkutan umum berbasis online ditinjau dari Undang-Undang Nomor 22 Tahun 2009 Tentang Lalu Lintas dan Angkutan Jalan dan dan Peraturan Pemerintah Nomor 32 Tahun 2016 tentang Penyelenggaraan Angkutan orang dengan Kendaraan Bermotor Umum tidak dalam Trayek. Penelitian ini menggunakan metode pendekatan yuridus normative, yaitu penelitian hukum yang dilakukan dengan cara meneliti bahan pustaka atau yang disebut dengan data sekunder, berupa hukum positif dan bagaimana impelementasinya. Perlindungan hukum bagi penumpang adalah suatu masalah yang besar dengan persaingan global yang terus berkembang sehingga perlindungan hukum sangat dibutuhkan dalam persaingan global.
\end{abstract}

Kata Kunci: Perlindungan hukum, tarif pengguna angkutan berbasis online. 


\section{PENDAHULUAN}

\section{A. Latar Belakang Masalah}

Transportasi atau pengangkutan merupakan bidang kegiatan yang sangat penting dalam kehidupan masyarakat Indonesia. Pentingnya transportasi bagi masyarakat Indonesia disebabkan oleh beberapa faktor antara lain, keadaan geografis Indonesia yang terdiri dari ribuan pulau kecil dan besar, perairan yang terdiri dari sebagian besar laut, sungai dan danau yang memungkinkan pengangkutan dilakukan melalui darat, perairan, dan udara guna menjangkau seluruh wilayah Indonesia (Abdul Kadir Muhammad, Hukum Pengangkutan Niaga, Bandung: Citra Aditya Bakti, 1998, hal.7)

Hal lain yang juga tidak kalah pentingnya akan kebutuhan alat transportasi adalah kebutuhan kenyamanan, keamanan, dan kelancaranpengangkutan yang menunjang pelaksanaan pembangunan yang berupa penyebarankebutuhan pembangunan, pemerataan pembangunan, dan distribusi hasil pembangunandiberbagai sektor ke seluruh pelosok tanah air misalnya, sektor industri, perdagangan,pariwisata, dan pendidikan.

Menurut Undang-Undang No. 22 Tahun 2009 angkutan adalah sarana untuk memindahkan orang atau barang dari suatu tempat ke tempat lain. Tujuannya membantu orang atau kelompok orang menjangkau berbagai tempat yang dikehendaki, atau mengirimkan barang dari tempat asalnya ketempat tujuannya. Prosesnya dapat dilakukan menggunakan sarana angkutan berupa kendaraan atau tanpa kendaraan (diangkut oleh orang).

Secara umum, masyarakat yang melakukan pergerakan dengan tujuan yang berbedabedamembutuhkan sarana penunjang pergerakan berupa angkutan pribadi (mobil, motor)maupun angkutan umum (paratransit dan masstransit). Angkutan umum paratransitmerupakan angkutan yang tidak memiliki rute dan jadwal yang tetap dalam beroperasidisepanjang rutenya, sedangkan angkutan umum masstransit merupakan angkutan yangmemiliki rute dan jadwal yang tetap serta tempat pemberhentian yang jelas (Sugiyono, Metode Penelitian Kuantitatif Kualitatif dan $R \&$ D, Bandung: Alfabeta, 2011, hal. 23).

Pembangunan hukum tidak hanya menambah peraturan baru atau merubah peraturan lama dengan peraturan baru tetapi juga harus dapat memberikan kepastian dan perlindungan hukum bagi semua pihak yang terkait dengan sistem transportasi terutama pengguna jasatransportasi. Mengingat penting dan strateginya peran lalu-lintas dan angkutan jalan yangmenguasai hajat hidup orang banyak serta sangat penting bagi seluruh 
masyarakat, makapembangunan dan pengembangan prasarana dan sarana pengangkutan perlu di tata dan dikembangkan dalam sistem terpadu (Suwardjoko Warpani, Pengelolaan Lalu Lintas dan Angkutan Jalan, Bandung: ITB, hal. 13)

Angkutan memegang peranan yang sangat vital karena tidak hanya sebagai alat fisik, alat yang harus membawa barang-barang yang diperdagangkan dari produsen ke konsumen, tetapi juga sebagai alat penentu harga dari barang-barang tersebut (H.M.H. Purwosutjipto, Pengertian Pokok dalam Hukum Dagang Indonesia Jilid 4 bagian kedua, Jakarta: Jambatan, 2005, hal. 2)

Pembahasan pembangunan aspek hukum transportasi tidak terlepas dari efektivitas hukum pengangkutan itu sendiri. Pengangkutan di Indonesia diatur dalam Kitab Undangundang Hukum Perdata pada Buku Ketiga tentang perikatan, kemudian dalam Kitab Undang-undang Hukum Dagang pada Buku II titel ke V.

\section{B. Identifikasi Masalah}

1. Perlindungan hukum terhadap tarif pengguna jasa angkutan umum berbasis online ditinjau dari Undang-Undang Nomor 22 Tahun 2009 Tentang Lalu Lintas dan Angkutan Jalan dan Peraturan Pemerintah Nomor 32 Tahun 2016 tentang Penyelenggaraan Angkutan orang dengan Kendaraan Bermotor Umum tidak dalam Trayek.

2. Bentuk penetapan tarif pengguna jasa angkutan umum berbasis online ditinjau dari Undang-Undang Nomor 22 Tahun 2009 Tentang Lalu Lintas dan Angkutan Jalan dan dan Peraturan Pemerintah Nomor 32 Tahun 2016 tentang Penyelenggaraan Angkutan orang dengan Kendaraan Bermotor Umum tidak dalam Trayek.

\section{Perumusan Masalah}

1. Bagaimana perlindungan hukum terhadap tarif pengguna jasa angkutan umum berbasis online ditinjau dari Undang-Undang Nomor 22 Tahun 2009 Tentang Lalu Lintas dan Angkutan Jalan dan Peraturan Pemerintah Nomor 32 Tahun 2016 tentang Penyelenggaraan Angkutan orang dengan Kendaraan Bermotor Umum tidak dalam Trayek?

2. Bagaimana bentuk penetapan tarif pengguna jasa angkutan umum berbasis online ditinjau dari Undang-Undang Nomor 22 Tahun 2009 Tentang Lalu Lintas dan Angkutan Jalan dan dan Peraturan Pemerintah Nomor 32 Tahun 2016 tentang 
Penyelenggaraan Angkutan orang dengan Kendaraan Bermotor Umum tidak dalam Trayek?

\section{Metode Penulisan dan Analisis Data}

1. Metode Pendekatan

Dalam penulisan tesis ini penulis menggunakan metode pendekatan yuridis normatif, yaitu suatu penelitian yang menekankan pada ilmu hukum tetapi disamping itu juga menelaah kaidah hukum yang berlaku dalam masyarakat.Metode pendekatan yuridis normatif digunakan dengan tujuan untuk menganalisis kepastian hukum.

2. Sifat Penelitian

Sifat penelitian ini adalah Preslapsi yaitu penelitian yang bersifat memberikan petunjuk dari suatu aturan resmi.

3. Jenis Data Sekunder

a. Bahan Hukum primer merupakan bahan hukum yang bersifat autoritatif artinya memiliki suatu otoritas, mutlak dan mengikat Bahan hukum primer terdiri dari peraturan dasar, peraturan perundang-undangan, catatan resmi, lembar Negara penjelasan, risalah, putusan hakim dan yurisprudensi. Dalam hal ini penulis menggunakan bahan hukum primer:

1) Undang-undang Nomor 22 Tahun 2009 Tentang Lalulintas Dan Angkutan Jalan.

2) Undang-undang Nomor 8 Tahun 1999 Tentang Perlindungan Konsumen

3) Peraturan Pemerintah Nomor 32 Tahun 2016 Tentang Penyelenggaraan Angkutaan Orang Dengan Kendaraan Bermotor Umum Tidak Dalam Trayek.

b. Bahan Hukum Sekunder, yaitu bahan-bahan yang memberikan penjelasan mengenai bahan hukum primer, berupa hasil karya dari kalangan hukum dalam bentuk buku-buku atau artikel.

c. Bahan hukum tersier, yaitu bahan-bahan yang memberikan informasi tentang bahan hukum primer dan bahan hukum sekunder, berupa kamus-kamus keilmuan, seperti kamus istilah hukum, bisnis, dan ekonomi.

4. Metode Pengambilan Data

Data sekunder diperoleh dengan melakukan inventarisasi peraturan perundangundangan, dokumen resmi, dan literatur yang kemudian dicatat berdasarkan 
relevansinya dengan pokok permasalahan untuk kemudian dikaji sebagai suatu kajian yang utuh.

5. Analisis Data

Analisis data merupakan kebenaran penelitian yang koherensi, yaitu peraturan hukum yang harus koren terhadap norma hukum dan norma hukum terhadap prinsip hukum.

Berdasarkan hasil pembahasan diambil kesimpulan sebagai jawaban terhadap permasalahan yang diteliti. Dengan demikian kesimpulan yang dihasilkan akan menunjukan dan menjelaskan obyektifitas dari proses dan hasil penelitian tesis ini.

\section{PEMBAHASAN}

\section{A. Pengangkutan}

\section{Pengertian Pengangkutan}

Istilah "Pengangkutan" berasal dari kata "angkut" yang berarti "mengangkut dan membawa", sedangkan istilah "pengangkutan" dapat diartikan sebagai "pembawaan barang-barang atau orang-orang (penumpang)". Menurut H.M.N Purwosutjipto dalam bukunya Pengertian Pokok Hukum Dagang Indonesia, jenis-jenis pengangkutan terdiri dari pengangkutan darat, pengangkutan laut, pengangkutan udara, dan pengangkutan perairan darat (HMN Purwosutjipto, Op Cit., hal. 4).

Angkutan adalah suatu keadaan pemindahan orang dan atau barang dari suatu tempat lain dengan suatu tujuan tertentu, baik untuk memperoleh nilai tambah untuk barang/komersial maupun untuk tujuan nonkomersial (E.Suherman, Aneka masalah hukum kedirgantaraan, Bandung: Ganesha, 2002, hal. 293)

Menurut Utomo, transportasi adalah pemindahan barang dan manusia dari tempat asal ke tempat tujuan. Pengertian yang lebih luas dikemukakan oleh Suharto yang menyatakan: "transportasi adalah perpindahan dari suatu tempat ke tempat lainnya dengan menggunakan alat pengangkutan, baik digerakkan oleh tenaga manusia (becak), hewan (kuda, sapi, kerbau) ataupun mesin. Konsep transportasi didasarkan pada adanya perjalanan (trip) antara asal (origin) dan tujuan (destination)" (Sution Usman Adji, Djoko Prakoso dan Hari Pramono, Op Cit., hal. 12) 


\section{Asas Pengangkutan}

a. Asas yang bersifat public

1) Asas Transparan yaitu keterbukaan dalam penyelenggaraan lalu lintas dan angkutan jalan kepada masyarakat luas dalam memperoleh informasi yang benar, jelas, dan jujur sehingga masyarakat mempunyai kesempatan berpartisipasi bagi pengembangan lalu lintas dan angkutan jalan.

2) Asas Akuntabel yaitu penyelenggraan lalu lintas dan angkutan jalan yang dapat dipertanggungjawabkan.

3) Asas Berkelanjutan yaitu penjamin kualitas fungsi lingkungan melalui pengaturan persyaratan teknis laik kendaraan dan rencana umum pembangunan serta pengembangan jaringan lalu lintas dan angkutan jalan.

4) Asas Partisipatif yaitu pengaturan peran serta masyarakat dalam proses penyusunan kebijakan, pengawasan terhadap pelaksanaan kebijakan, penanganan kecelakaan, dan pelaporan atas peristiwa yang terkait dengan lalu lintas dan angkutan jalan.

5) Asas Bermanfaat yaitu semua kegiatan penyelenggaraan lalu lintas dan angkutan jalan yang dapat memberikan nilai tambah sebesar-besarnya dalam rangka mewujudkan kesejahteraan masyarakat.

6) Asas Efisien dan Efektif yaitu pelayanan dalam penyelenggaraan lalu lintas dan angkutan jalan yang dilakukan oleh setiap pembina pada jenjang pemerintahan secara berdaya guna dan berhasil guna.

7) Asas Seimbang yaitu penyelenggaraan lalu lintas dan angkutan jalan yang harus dilaksanakan atas dasar keseimbangan antara sarana dan prasarana serta pemenuhan hak dan kewajiban pengguna jasa dan penyelenggara

8) Asas Terpadu yaitu penyelenggaraan pelayanan lalu lintas dan angkutan jalan yang dilakukan dengan mengutamakan keserasian dan kesaling bergantungan kewenangan dan tanggung jawab antar instansi pembina.

9) Asas Mandiri yaitu upaya transportasi asas tersebut dimaksudkan bahwa pengangkutan dijadikan alat transportasi yang dapat menunjang bagi masyarakat dan negara agar terdapat keterpaduan intra maupun antar transportasi lain, baik darat, laut, ataupun di udara. 
b. Asas pengangkutan bersifat perdata

Merupakan landasan hukum yang hanya berlaku bagi para pihak yang telah membuat perjanjian pengangkutan yaitu pengangkut dan penumpang. Asas bersifat perdata ini didasarkan pada Pasal 186 Undang-Undang Nomor 22 Tahun 2009 Tentang Lalu Lintas dan Angkutan Jalan yaitu, perusahaan angkutan umum wajib mengangkut orang dan/atau barang setelah disepakati perjanjian angkutan dan/atau dilakukan pembayaran biaya angkutan oleh penumpang dan/atau pengirim barang. Berdasarkan pasal tersebut maka asas yang terdapat pada asas hukum perdata yaitu.

c. Tujuan pengangkutan

Pada dasarnya tujuan pengangkutan adalah untuk memindahkan barang atau orang dari suatu tempat yang lain dengan maksud untuk meningkatkan daya guna dan nilai. Jadi dengan pengangkutan maka dapat diadakan perpindahan barangbarang dari suatu tempat yang dirasa barang itu kurang berguna ketempat dimana barang-barang tadi dirasakan akan lebih bermanfaat. Perpindahan barang atau orang dari suatu tempat ketempat yang lain yang diselenggarakan dengan pengangkutan tersebut harus dilakukan dengan memenuhi beberapa ketentuan yang tidak dapat ditinggalkan, yaitu harus diselenggarakan dengan aman, selamat, cepat, tidak ada perubahan bentuk tempat dan waktunya.

\section{Pengertian Hukum Pengangkutan Darat}

Kata pengangkutan berasal dari kata dasar angkut yang berarti mengangkat dan membawa. Dalam kamus hukum tercantum bahwa, pengangkutan adalah perjanjian timbal balik antara pengangkut dengan pengirim, di mana pengangkut mengikatkan diri untuk menyelenggarakan pengangkutan barang dan/atau orang dari suatu tempat ke tempat tujuan tertentu dengan selamat, sedangkan pengirim mengikatkan diri untuk membayar uang angkutan (Setiawan Widagdo, Kamus Hukum, Jakarta: Prestasi Pustaka, 2012, hal. 413)

Keberadaan kegiatan pengangkutan tidak dapat dipisahkan dari kegiatan atau aktivitas kehidupan manusia sehari-hari. Pengangkutan adalah "orang yang mengikatkan diri untuk menyelenggarakan pengangkutan barang dan/atau orang dari suatu tempat ke tempat tujuan tertentu dengan selamat" (Siti Utari, Pengangkutan Laut, Jakarta: Balai Pustaka, 1994. hal. 6) 
Pengertian pengangkutan menurut hukum dagang adalah "orang yang baikkarena penggunaan penyediaan kapal menururt waktu (carter waktu) atau penggunaan penyediaan kapal menurut perjalanan (carter perjalanan), baik dengan suatu persetujuan lain, mengikatkan diri untuk menyelenggarakan pengangkutanbarang yang seluruhnya atau sebagian melalui laut.” (Pasal 466 Buku II Tentang Pengangkutan Barang Kitab Undang Undang Hukum dagang).

Pengangkutan adalah kegiatan pemuatan penumpang atau barang kedalam alat pengangkut, pemindahan penumpang atau barang ketempat tujuan dengan alat pengangkut, dan penurunan penumpang atau pembongkaran barang dari alat pengangkut ketempat tujuan yang disepakati (Pasal 466 Buku II Tentang Pengangkutan Barang Kitab Undang Undang Hukum Dagang).

Sedangkan hukum pengangkutan adalah sebuah perjanjian timbal-balik, yang mana pihak pengangkut mengikat diri untuk untuk menyelenggarakan pengangkutan barang dan/atau orang ketempat tujuan tertentu, sedangkan pihak lainnya (pengirim atau penerima, penumpang) berkeharusan untuk menunaikan pembayaran biaya tertentu untuk pengangkutan tersebut

\section{Hak Dan Kewajiban Penyedia Jasa Pengangkutan Darat Online Berbasis Aplikasi Dalam Melaksanakan Kegiatan Pengangkutan Darat}

Undang-Undang Nomor 8 Tahun 1999 Tentang Perlindungan Konsumen menyebutkan penyedia jasa atau pelaku usaha adalah "setiap orang perorangan atau badan usaha, baik yang berbentuk badan hukum maupun bukan badan hukum yang didirikan dan berkedudukan atau melakukan kegiatan dalam wilayah hukum nasional, baik secara sendiri maupun secara bersama-sama melalui perjanjian menyelenggarakan kegiatan usaha dalam berbagai bidang ekonomi" (Pasal 1 Angka 3 Undang-Undang Nomor 8 Tahun 1999 Tentang Perlindungan Konsumen).

Pengertian pelaku usaha dalam undang-undang tersebut sangat luas, cakupan luasnya pengertian pelaku usaha dalam undang-undang tersebut memiliki persamaan dengan pengertian pelaku usaha dalam masyarakat dunia, bahwa yang dapat dikulaifikasi sebagai produsen adalah pembuat produk jadi (finished product), penghasil bahan baku, pembuat suku cadang, setiap orang yang menampakkan dirinya sebagai produsen, dengan jalan mencantumkan namanya, tanda pengenal tertentu, atau tanda 
lain yang membedakan dengan produk asli, pada produk tertenu, importir suatu produk dengan maksud untuk diperjualbelikan, disewakan, disewagunakan (leasing) atau bentuk distribusi lain dalam transaksi perdagangan, pemasok (suplier), dalam hal identitas dari produsen atau importir tidak dapatditentukan (Ahmadi Miru \& Sutarrnan Yodo, Hukum Perlindungan Konsumen, Cetakan Kedua, Jakarta: Raja Grafindo Persada, 2004, hal. 8)

\section{Aturan-Aturan Hukum Jasa Pengangkutan Darat Online BerbasisAplikasi}

Pasal 1 Angka 15 Undang-Undang Nomor 13 Tahun 2003 Tentang Ketenagakerjaan mendefinisikan hubungan kerja sebagai hubungan antara pengusaha dengan pekerja/buruh berdasarkan perjanjian kerja, yang mempunyai unsure pekerjaan, upah, dan perintah. Dari pengertian itu terlihat tiga unsurhubungan kerja, yaitu: 1) Pekerjaan, unsur ini terpenuhi jika pekerja hanya melaksanakan pekerjaan yang sudah diberikan perusahaan. Dalam praktiknya, driver go-jek atau grab taxi tidak menerima perintah kerja dari perusahaan, melainkan dari pelanggan ojek dan dikerjakan secara pribadi seperti halnya tukang ojek pada umumnya. 2) Upah, unsur ini terpenuhi jika pekerja menerima kompensasi berupa uang tertentu yang besar jumlahnya tetap dalam periode tertentu, bukan berdasarkan komisi atau bagi hasil. Driver tidak mendapatkan gaji dari perusahaan, justru para driver harus membagi 20 (dua puluh) persen pendapatannya ke perusahaan.

6. Perlindungan hukum terhadap tarif pengguna jasa angkutan umum berbasis online ditinjau dari Undang-Undang Nomor 22 Tahun 2009 Tentang Lalu Lintas dan Angkutan Jalan dan Peraturan Pemerintah Nomor 32 Tahun 2016 tentang Penyelenggaraan Angkutan orang dengan Kendaraan Bermotor Umum tidak dalam Trayek

Perlindungan Hukum Melalui Undang-Undang Nomor 8 Tahun 1999 Tentang Perlindungan Konsumen. Pengaturan tentang hukum perlindungan konsumen telah diatur dalam Undang-Undang Nomor 8 Tahun 1999 Tentang Perlindungan Konsumen. Berdasarkan undang-undang tersebut disebutkan bahwa "perlindungan konsumen adalah segala upaya yang menjamin adanya kepastian hukum untuk memberi 
perlindungan kepada konsumen" (Pasal 1 Angka 1 Undang-Undang Nomor 8 Tahun 1999 Tentang Perlundungan Konsumen)

Kepastian hukum untuk memberi perlindungan kepada konsumen berupa perlindungan terhadap hak-hak konsumen, yang diperkuat melalui undang-undang khusus, memberi harapan agar pelaku usaha tidak bertindak sewenang-wenang yang selalu merugikan hak-hak konsumen (Happy Susanto, Hak-Hak Konsumen Jika Dirugikan, Jakarta: Visimedia, 2008, hal.4). Dengan adanya Undang-Undang Nomor 8 Tahun 1999 Tentang Perlindungan Konsumen beserta perangkat hukum lainnya, konsumen memilikihak dan posisi yang berimbang dan mereka dapat menggugat atau menuntut jika ternyata hak-haknya telah dirugikan atau dilanggar oleh pelaku usaha (Ibid., hal.5).

Hukum perlindungan konsumen yang berlaku saat ini memiliki dasar hukum yang telah ditetapkan oleh pemerintah, dengan adanya dasar hukum yang pasti, perlindungan terhadap hak-hak konsumen bisa dilakukan dengan penuh optimisme. Pengertian perlindungan konsumen yang termaktub dalam undang- undang ditujukan untuk memberikan perlindungan kepada konsumen itu antara lain adalah dengan meningkatkan harkat dan martabat konsumen serta membuka akses informasi tentang barang dan/atau jasa bagi konsumen, dan menumbuhkembangkan sikap pelaku usaha yang jujur dan bertanggung jawab (Adrian Sutedi, Tanggung Jawab Produk Dalam Hukum Perlindungan Konsumen, Jakarta:GhaliaIndonesia,2008, hal.8)

AZ Nasution berpendapat bahwa:"Hukum perlindungan konsumen adalah bagian dari hukum konsumen yang memuat asas-asas atau kaidah-kaidah yang bersifat mengatur dan mengandung sifat yang melindungi kepentingan konsumen, sedangkan hukum konsumen adalah hukum yang mengatur hubungan dan masalah antara berbagai pihak satu sama lain berkaitan dengan barang atau jasa konsumen di dalam pergaulan hidup" AZ. Nasution, Hukum Perlindungan Konsumen Suatu Pengantar. Jakarta: Diadit Media, 2001, hal.11).

\section{Bentuk penetapan tarif pengguna jasa angkutan umum berbasis online}

a. Jenis Angkutan Sewa

Terdapat perubahan definisi Angkutan Sewa. Sebelumnya angkutan sewa didefinisikan sebagai pelayanan angkutan dari pintu ke pintu yang disediakan 
dengan cara menyewa kendaraan dengan atau tanpa pengemudi. Direvisi menjadi pelayanan angkutan dari pintu ke pintu yang disediakan dengan cara menyewa kendaraan. Angkutan sewa terdiri atas angkutan sewa umum dan angkutan sewa khusus. Angkutan Sewa Umum merupakan pelayanan angkutan dari pintu ke pintu yang disediakan dengan cara menyewa kendaraan dengan atau tanpa pengemudi melalui cara borongan berdasarkan jangka waktu tertentu. Angkutan Sewa Khusus merupakan pelayanan angkutan dari pintu ke pintu yang wilayah operasinya dalam kawasan perkotaan, disediakan dengan cara menyewa kendaraan dengan pengemudi, dan pemesanan menggunakan aplikasi berbasis teknologi informasi.

\section{b. Ukuran CC Kendaraan}

Baik angkutan sewa umum maupun angkutan sewa khusus menggunakan kendaraan mobil penumpang umum minimal $1.000 \mathrm{CC}$.

c. Tarif

Pembayaran tarif angkutan sewa umum sesuai dengan perjanjian antara pengguna jasa dan perusahaan angkutan.Sedangkan tarif angkutan sewa khusus tertera pada aplikasi berbasis teknologi informasi dan sesuai dengan perjanjian antara pengguna jasa dan perusahaan angkutan.

\section{d. Kewajiban Surat Tanda Nomor Kendaraan Berbadan Hukum}

Jika sebelumnya ketentuan Surat Tanda Nomor Kendaraan atas nama perusahaan, direvisi menjadi Surat Tanda Nomor Kendaraan atas nama badan hukum, paling sedikit memiliki 5 (lima) kendaraan dilengkapi dengan surat tanda bukti lulus uji berkala kendaraan bermotor.

e. Pengujian Berkala (KIR)

Bukti lulus uji berkala kendaraan bermotor akan dilakukan dengan pemberian plat yang di-emboss nomor uji.

\section{f. Pool}

Kewajiban memiliki tempat penyimpanan kendaraan (pool) direvisi menjadi tempat penyimpanan kendaraan yang mampu menampung sesuai jumlah kendaraan yang dimiliki (kata 'pool' dihilangkan). 
g. Bengkel

Kewajiban menyediakan fasilitas pemeliharaan kendaraan (bengkel) yang dibuktikan dengan dokumen kepemilikan atau perjanjian kerjasama dengan pihak lain. Ketentuan ini mengakomodir permintaan atau tuntutan untuk dapat bekerjasama dengan pihak lain yang memiliki bengkel.

h. Pajak

Terdapat tambahan ketentuan baru masukan dari Ditjen Pajak, yaitu mengenai kriteria Perusahaan penyedia aplikasi berbasis Teknologi Informasi (TI) yang melakukan usaha di Indonesia. Perusahaan penyedia aplikasi berbasis Teknologi Informasi wajib berbadan hukum Indonesia dengan kriteria minimal:

1) melakukan kontrak, penjualan dan/atau penyerahan jasa, dan penagihan;

2) memiliki rekening bank yang menjadi sarana penampungan hasil penjualan atau penyerahan jasa pada bank yang ada di Indonesia;

3) mempunyai/menguasai server atau pusat data (data centre) yang berdomisili di Indonesia;

4) melakukan Pemasaran, promosi, dan kegiatan asistensi lainnya; dan

5) menyediakan layanan dan penyelesaian pengaduan konsumen.

i. Akses Dashboard

Pokok bahasan Akses Dashboard merupakan ketentuan baru yang ditambahkan dalam revisi peraturan ini.Akses Dashboard yang dimaksud adalah akses yang diberikan oleh perusahaan penyedia aplikasi berbasis Teknologi Informasi kepada pemerintah untuk dapat memantau operasional pelayanan angkutan sehingga bermanfaat dalam pengawasan dan pembinaan operasional angkutan.

j. Sanksi

Penambahan Pasal baru (Pasal 62) yang mengatur prosedur pemberian sanksi kepada Perusahaan Penyedia Aplikasi Berbasis Teknologi Informasi dari Menkominfo berdasarkan rekomendasi dari Menteri Perhubungan. 


\section{KESIMPULAN DAN SARAN}

\section{A. Kesimpulan}

1. Perlindungan hukum terhadap tarif pengguna jasa angkutan umum berbasis online ditinjau dari Undang-Undang Nomor 22 Tahun 2009 Tentang Lalu Lintas dan Angkutan Jalan dan Peraturan Pemerintah Nomor 32 Tahun 2016 tentang Penyelenggaraan Angkutan orang dengan Kendaraan Bermotor Umum tidak dalam Trayek Perlindungan hukum dalam undang-undang ini terlihat secara tegas, dimana dinyatakan bahwa “angkutan umum wajib mengangkut orang dan/atau barang, setelah disepakati perjanjian pengangkutan dan/atau dilakukannya pembayaran biaya angkutan oleh penumpang dan/atau pengiriman barang. Jadi bentuk perlindungan hukum yang didapat melalui revisi pasal 7 dan 11 Undang-undang Nomor 22 Tahun 2009 Tentang Lalu Lintas dan Angkutan Jalan menjadi Peraturan Pemerintah Nomor 32 Tahun 2016 tentang Penyelenggaraan Angkutan orang dengan Kendaraan Bermotor Umum tidak dalam Trayek sudah menjamin kepastian terhadap ketentuan tarif yang berlaku.

2. Bentuk penetapan tarif pengguna jasa angkutan umum berbasis online ditinjau dari Undang-Undang Nomor 22 Tahun 2009 Tentang Lalu Lintas dan Angkutan Jalan dan dan Peraturan Pemerintah Nomor 32 Tahun 2016 Tentang Penyelenggaraan Angkutan orang dengan Kendaraan Bermotor Umum tidak dalam Trayek Berdasarkan aturan yang ada, sudah disama-ratakan dengan peraturan penetapan tariff taxi pada umumnya berdasarkan Peraturan Pemerintah Nomor 32 Tahun 2016 Tentang Penyelenggaraan Angkutan orang dengan Kendaraan Bermotor Umum tidak dalam Trayek yang di jelaskan dalam Pasal 42. Secara Defacto roda dua sudah menjadi kebutuhan dan hajat hidup orang banyak, jadi selama roda dua masih rasional dalam arti tidak mengabaikan standar keamaanan lalu lintas sudah saatnya roda dua masuk kategori angkutan umum. Dalam menyusun Undang-Undang lalu lintas harus mengikuti perkembangan dan kebutuhan masyarakat, tentu spesifikasinya perlu diperketat layaknya transportasi umum roda empat. Maraknya TBO menunjukkan adanya keinginan masyarakat mencari alternatif transportasi yang murah dan cepat sebagai respons terhadap buruknya layanan transportasi umum yang disediakan pemerintah. Harus diakui, perkembangan teknologi alat transportasi berbasis online semakin mempermudah konsumen untuk memilih angkutan yang sesuai dengan keinginan mereka. 


\section{B. Saran}

1. Sebaiknya pemerintah membuat peraturan pelaksana yang spesifik mengenai pengangkutan darat berbasis aplikasi online, agar tercipta bentuk perlindungan terhadap keamanan dan keselamatan penumpang secara umum yang dapat memayungi hak dan keselamatan pengguna transportasi online dengan begitu masyarakat yang menggunakan jasa angkutan umum berbasis omline mempunyai kepastian hukum.

2. Seharusnya perusahaan penyedia jasa pengangkutan darat berbasis aplikasi online, tetap harus ikut andil bila terjadi kecelakaan pengangkutan darat, walaupun status kedudukannya hanya sebagai penghubung, namun perusahaan sharusnya mempertimbangkan aspek perlindungan konsumen. Seharusnya penumpang lebih bijak menggunakan pengangkutan darat berbasis aplikasi online, bukan hanya mencari alternatif mudah dan mengesampingkan aspek keselamatan berkendara.

\section{DAFTAR PUSTAKA}

\section{$\underline{\text { Buku }}$}

Abdul Kadir Muhammad, Hukum Pengangkutan Niaga, Bandung: Citra Aditya Bakti, 1998. Abdulkadir Muhammad, Hukum Pengangkutan Niaga, Bandung: Citra Aditya Bakti, 2008.

Adrian Sutedi, Tanggung Jawab Produk Dalam Hukum Perlindungan Konsumen, Jakarta:Ghalia Indonesia,2008.

Ahmadi Miru \& Sutarrnan Yodo, Hukum Perlindungan Konsumen, Cetakan Kedua, Jakarta: Raja Grafindo Persada, 2004.

Aminuddin Hukum Tata Pemerintahan, Jakarta: Kharisma Putra Utama. 2001.

AZ. Nasution, Hukum Perlindungan Konsumen Suatu Pengantar. Jakarta: Diadit Media, 2001.

E.Suherman, Aneka masalah hukum kedirgantaraan, Bandung: Ganesha, 2002.

H.M.N. Purwosutjipto, Pengantar Pokok Hukum Dagang Indonesia: Hukum Pengangkutan, Jakarta: Djambatan, 1981.

H.M.H. Purwosutjipto, Pengertian Pokok dalam Hukum Dagang Indonesia Jilid 4 bagian kedua, Jakarta: Jambatan, 2005.

Happy Susanto, Hak-Hak Konsumen Jika Dirugikan, Jakarta: Visimedia, 2008, hal. 4 HMN Purwosutjipto.

Romli Atmasasmita, TeoriHukum Integratif: Rekonstruksi terhadap Teori Hukum Pembangunan dan Teori Hukum Progresif, Yogyakarta: Genta Publishing, 2012. 
Setiawan Widagdo, Kamus Hukum, Jakarta: Prestasi Pustaka, 2012.

Siti Utari, Pengangkutan Laut, Jakarta: Balai Pustaka, 1994.

Sugiyono, Metode Penelitian Kuantitatif Kualitatif dan $R \& D$, Bandung: Alfabeta, 2011.

Sution Usman Adji ,Hukum Pengangkutan Di Indonesia, Jakarta: Rinka Cipta, 1991.

Sution Usman Adji, Djoko Prakoso dan Hari Pramono.

Sution Usman Adji, Djoko Prakoso, Hukum Pengangkutan di Indonesia, Jakarta: Rineka Cipta, 1990.

Suwardjoko Warpani, Pengelolaan Lalu Lintas dan Angkutan Jalan, Bandung: ITB.

W.Riawan Tjandra, Hukum Sarana Pemerintahan. Yogyakarta:Cahaya Atma Pustaka Yogyakarta. 2003.

\section{Peraturan Perundang-undangan}

Pasal 1 Angka 1 Undang-Undang Nomor 8 Tahun 1999 Tentang Perlundungan Konsumen.

Pasal 1 Angka 3 Undang-Undang Nomor 8 Tahun 1999 Tentang Perlindungan Konsumen.

Pasal 466 Buku II Tentang Pengangkutan Barang Kitab Undang Undang Hukum dagang. 